\title{
Tourism In The Serbian,
} Romanian And Hungarian Borderline Area As Part Of Cross-border Cooperation

\section{Željko Bjeljac', Nevena Ćurčić ${ }^{2}$}

\begin{abstract}
In this paper, there have been presented potentials and possibilities for the development of tourism in borderline areas of Serbia, Romania and Hungary. Apart from the existing differences, there are similarities in the geographic space, similar historic events, religious and other demographic characteristics, attractive tourist sites in the borderline areas of Serbia, Romania and Hungary, representing compatible tourist cross-border regions. Dominant tourist activities in the observed area are: transit tourism on the rivers of Danube and Tisza, spa, cultural, event, religious, sports and recreational and rural tourism. Tradition, folklore and lifestyle are based on the multiethnic characteristisc of the area and other economic conditions represented in these tourist regions. The establishment of cross-border regions emphasizes the possibilities for the stronger cultural, economic, sports, scientific, technological and other forms of cooperation among Serbia, Romania and Hungary, as well as among other countries in the region. The Euroregion DanubeTisza-Kris-Mures on the cross-border area of Serbia, Hungary and Romania, the Djerdap Gorge on the Serbian and Romanian crossborder area as cross-border eco-park and tourist region, have a potential to develop as an important international tourist destination on the global tourist market.
\end{abstract}

Key words: Serbia, Romania, Hungary, cross-border, cooperation

1 Geographical Institute "Jovan Cvijic", Serbian Academy of Science and Arts, Djure Jaksica 9, Belgrade, Serbia, E-mail: zbjeljac@yahoo.com

2 Department for Geography, Tourism and Hotel Industry, Faculty of natural sciences, University of Novi Sad, Serbia, e-mail: galant @ptt.yu

\section{Introduction}

Relations in tourism, different stages of development of contemporary society, different theoretical and practical approaches towards tourist regionalization are set of conditions for separating attractive tourist areas. The current differences on this observed area because of similar geo-space, historical events, similar demographic features, similar religions as well as other anthropogenic factors may become, on the contrary, common features that could turn this region into important tourist destination. This area is now in the social and economic transitions. "Strictly defined, a "transition" is movement between two specific points" (Hall 2004), the final points in the case of Serbia, Hungary and Romania, being integration into the world economy and Western European institutions, notably the European Union. Tour ist regions present the elements that could help in solving socio-political and economic problems in those countries. Although the development of those countries is complicated because of the political, social and economical difficulties, attractive tourist areas are the elements, which can enable quicker economical and social development and the European Union membership.

Process of globalization and the biggest inter subordination between states greatly benefit from the tourist industry. Tourist industry changes ways in production and consumption, leading to greater competitiveness, presentation of new marketing methods, to standard quality development and global market. Market liberalization growth, in other words, economy, various goods and services, development of faster and safer means of transport as well as the appearance of new information technology, are basic factors in economical, tourist and recreative development (Marjanovic, Randjelovic, 2002). In the context of the global networking and cooperation, tourist areas close to the borderline take part in tourist unity and cooperation of the similar natural regions and anthropogenic assets.

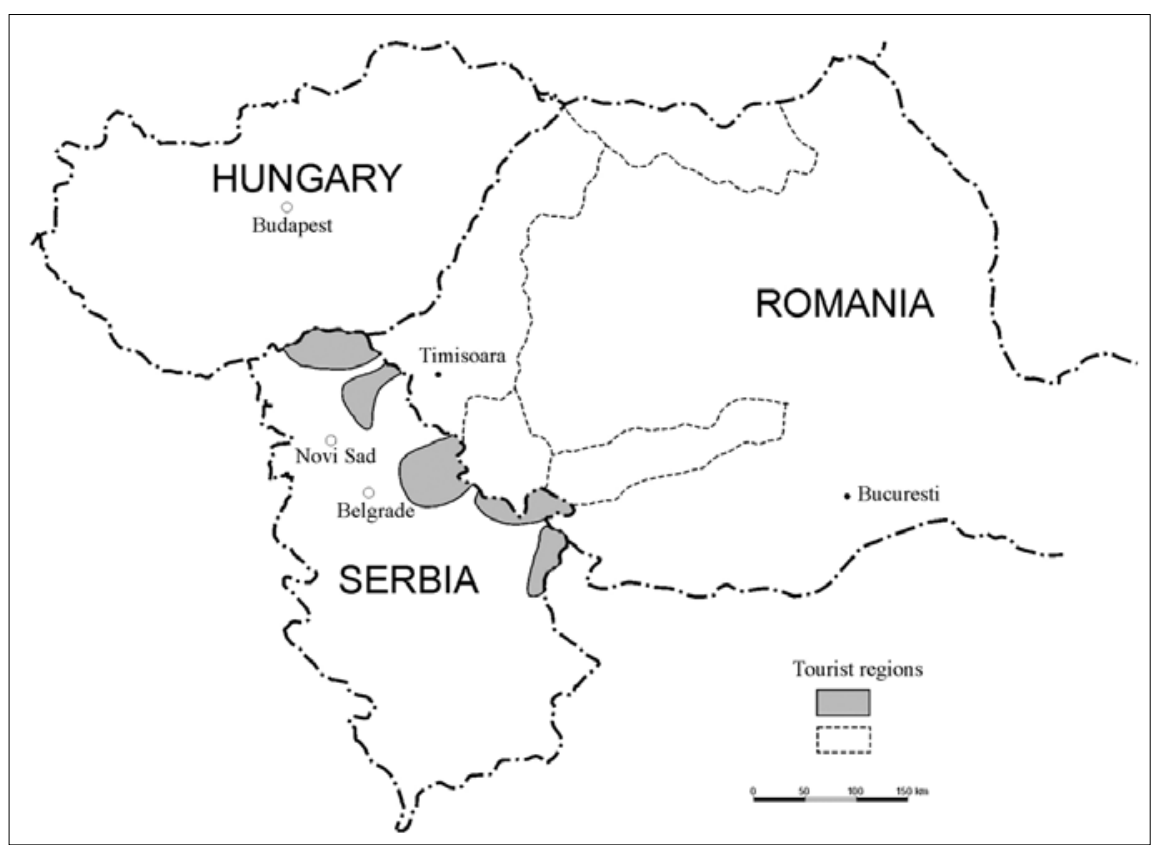

Figure 1 Tourist regions in border area beetwen Serbias, Hungary and Romania 
Mitrovic (2001) said "In the modern world, regionalism is both a form of expressing the process of globalization, in other words, of expressing internationalization of the production sources and new in respect to challenges and needs of spreading the modern market. In that sense, regionalization is a factor of development in economical and social sense. In national and transnational limits, it enables new combination of the production factors, resources and their mobilization, allocation and verification, based on the market rules. It all creates the state of the permanent motivation, mobility and competition. It motivates all members of the society (involved in production politics, science, education and culture) to be open to the processes of modernization and learning, trying to realize innovation, rationalization, democratization, integration and reforms.

man action and economy. In other words, there are possibilities for stronger cultural, economic, scientific, and other cooperation between Serbia, Romania and Hungary and with other countries in the region as well .

"Most models of tourism development have been based on the experience of market economies, and indeed international tourism open borders, a strong, flexible public sector and public sector responsiveness to change requirements: such qualities were in short supply in the former state socialist states” (Hall, 2006).“One of the more promising methodological approaches to define real tourism space is the functional approach. It is assumed that tourism space is functionally distinct subspace of geographical and social space, and the motive for this creation and develop-

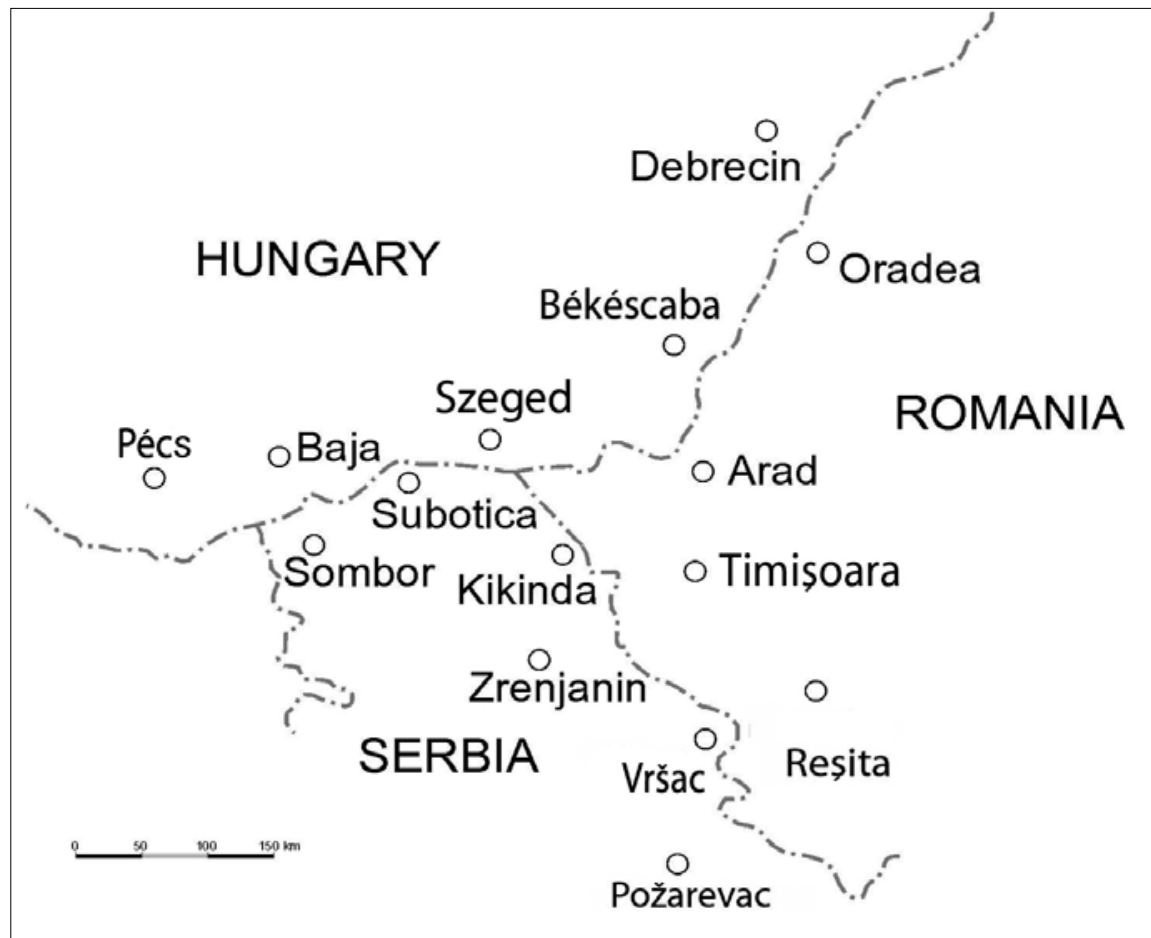

Figure 2 Border area between Serbia, Hungary and Romania

All in all, it implies the attitude opened to the world and its challenges." In the context of the global networking and cooperation, tourist areas close to a border take part in tourist uniting and cooperation of the similar natural regions and anthropogenic assets. The observed area is located in the area of two very important European traffic corridors ( 7 and 10), which marshrute is across Pannonian plain.

The tourist aspects that can be fully development are the following: transit, nautical tourism on rivers, spa, cultural, event, religious, sport, recreative and rural tourism. Traditions, customs, folklore, ways of living and entire economic development are present in those tourist regions. Tourist assets in those borderline areas stress the common life and cooperation of all the nationalities in various fields of hu- ment is the need for recreation, learning and new experience felt by the contemporary human. Tourism space is created by a person who uses the geographical and social environment, for tourism purposes and as a consequence discovers, organizes, uses, but also destroys it" (Liszevski, 2006).

Following this argument, we have distinguished, as a model of tourist development which boosts cross-border cooperation between Serbia, Romania and Hungary, natural tourist assets (relief, hydrographic, flora and fauna) and anthropogeography tourist assets (tradition, culture, customs, heritage, economy and multiethnic city) grouped in compact and comparative tourist regions, which represent potential tourist destinations of international importance.
Natural geographical tourist assets of the frontier area

The involvement of tourist assets in crossborder regions in the affirmative forms of tourism creates conditions for the establishment and intensification of cross-border and wider intergovernmental cooperation. Through its function of networking and interweaving of natural, cultural, historical and other elements of space, tourism easily lifts the border line between nations and countries opening the way to regional networking. "In most cases, crossborder tourist regions represent natural relief entities, creating opportunities for the formation of transnational tourist regions, as separate tourist destinations."(Bjeljac, Bursać,2005). Tourist trends are created as a result of the overlapping of interest of the four major elements:

- destination

- region with the attractive tourist asset

- population living on or near the locality which represents a tourist asset, and

- visitor drawn by the attractivenss of the tourist assets (Bjeljac et al, 2006)

These elements are under the strong influence of physical and geographical characteristics of the region where these interests overlap. They move and reproduce the identitz and the asset of each community. The relief, with its tourist functions (morphological relief, height above sea level and the incline of the terrain), represents basic territorial part of the physical and geographical enviroment with multifarious use. It connects the entire tourist activity (the distribution of the tourist demand, traffic infrastructure and tourist offer) and it represents the basic physical and geographic environment for the development of tourism. With its elements, the relief creates special tourist entities, connecting the geographical origin of the visitors, with the countries - tourist destinations, determing its traffic corridors, and influencing the quality, type and scope of the tourist infrastructure.

The Serbian-Romanian border area can be divided in the regional natural entities such as: mountain regions, attractive geomorphology assets, river valleys and lakes, plateau and lowland regions. The relief determines their traffic corridors, too and has an influence on the quality, type and scope of the tourist infrastructure, as well.

The mountains in the frontier region belong to Carpathian morph-tectonic system and they are: low mountainous regions and middle mountains include the great deal on the southern part of frontier area ${ }^{1}$. Those are the regions with great spa, sports-

1 Mountains .Semenji, Cerna, Mehedinti, Almas 
recreational and weekend- picnic tourism and possibilities for development of mountain, speleo, rural and eco tourism.

Plateau and plain regions include the great deal of the frontier area (Pannonian plain, on both sides), Banat sandy terrain, (on Serbian side). There are regions with great transit, weekend - picnic tourism and possibilities for development of eco- and rural tourism.

River valleys have their own tourist attractiveness, variety and specialty. According to the tourist assets in the border area are: Danube with artificial lakes Srebrno (Silver) and Djerdap, and with tributary Timish and Tisa tributary Begej, and spa's Buzias and Herculaneum (on Romanian side). Those are the regions with great sports- recreational, fishing, transit and weekend- picnic tourism. clude:

Attractive geomorphology assets in-

- canyons and gorges (Gorge of Djerdap with four sequential gorges: Golubac, Gospodjin Vir, Kazan (cauldrons) and Sip, and three depressions: Ljupskovska, Donji Milanovac and Orsava) (Vemic et all, 2003); Lazareva dolina (canyon) on river Zlotska on Kucaj mountain.

- Caves and other karsts assets: Lazareva (Zlotska), Vernjikica, Rajkova on $\mathrm{Ku}-$ caj mountain. Vantului cave in Padurea Crailui mountains, Clocoti ciul din Carca paretilor in Valcan mountains, Avenul din Grind (Grind Shaft) in Piatra Craiului Mountains.

In the Serbian-Hungarian border area, there can be divided the regional natural entities: plain regions and river valleys regions. Plain region include Pannonian plain with Baja-Subotica-Horgos sandy terrain. On Serbian side is Backa sandy terrain and Alfold (Great Hungarian plain) on Hungarian side. There are regions with great transit, weekend - picnic tourism and possibilities for development of eco and rural tourism.

River valleys have their own tourist attractiveness, variety and specialty. According to the tourist assets in the border area between certain rivers are significant: Danube with tributary Tisa (with Tisa tributaries Karas and Mures) lakes Palic, Ludosko, Kanjiza spa, Palic bath, (on Serbian side), (Bjeljac et al. 2002) Gyula, Oroshaza (on Hungarian side) (Tunde, 2001), spa baile Herculane (on Romanian side). Those are the regions with great spa, sports - recreational, fishing, transit and weekend- picnic tourism.

In the Romanian-Hungarian border area, there are regional natural entities, called plain regions. Plain regions include: Pannonian plain and Peripannonian area

side and mountains.Vrsacke, Kucajske, Deli Jovan and Miroc, from Serbian side. with sandy wasteland (called puszta) There are regions with possibilities for development of eco and rural tourism. Flo$\mathrm{ra}$ and fauna of the frontier regions are the bases for ecological, hunting, fishing, and picnic tourism because of their specific characteristics.

\section{Anthropogeography tourist assets of the frontier area}

As antropogenic influences on tourism we can distinguish: monument heritage, ethnographic motives, economic activity and settlements ${ }^{2}$. Anthropogenic tourist assets, as man made attractions, can be represented as: cultural (religion, modern culture, museums, art galleries, buildings, arechological sites etc.); traditional (folklore, festivals, culture); and events (sports, culture) (Bjeljac et al, 2006).

The space in border area, because of its natural geographic characteristics was an object of interest of the numerous civilizations, which had marked it with their own culture. Each of them had its own specific ethno- sociological, folklore and other characteristics. That kind of patrimony, with its rich and turbulent historical past, represents a significant tourist potential.

In consideration of historical settling different civilizations and zone of influence some imperials across history (Roman imperia, Ottoman imperia, AustroHungarian monarchy) and development in multiethnic states on this area (Serbia, Romania, Hungary, there are also significant cultural - historical monuments, sacred objects, and traditional architecture, old manufacture and folk arts and crafts products as important tourist localities. They are divided in groups or individually, as the complexes of archaeological, cultural, historical and art assets, as well as:

- Settlements-towns (tourist centers): Subotica, Sombor, Kikinda, Vrsac, Donji Milanovac, Kladovo, Mohac, Baja, Szeged, Bekeschaba, Debrecin, Oradea, Arad, Timisoara, Resita, Orsava.

- Archaeological emplacements (cultural and historical monuments from the prehistoric and antic Roman epoch): Lepenski vir, Tekija, Tabula Traiana, Gradac, Golubinje on Djerdap, The Roman archaeological complex at Tibiscum in the locality Jupa , archaeological complex at Praetorium, in the locality Mehadia.

Criteria for determining separate elements of an thropogenic heritage are the following: historic development, traditional customs and lifestyle, economic activity, religion, ethnic structure, cultural and historic heritage and tradition, origi nal settlement types and traditional architecture (Bjeljac, Ž, 1998; Development Strategy for Tour ism in Serbia, 1999)
- Ancient cities and fortresses: Golubac Ram, Fetislam, Castle of Gyula, Ruins of Timisoara Fortress, Huniady Castle in Timisoara.

- Sacred objects (Serbian and Romanian orthodox monasteries and Churches, Catholic samostans and churches).

- Other cultural and historical monuments from various epochs.

- Events (ethnographic, sport, economic, entertainment, arts): Karacsonyi vasar in Baja, Csalbai kolbaszfestival in Bekescaba, Fire dance Youth dance festival and Wine carnival in Debrecen, Nemzetkozi Tiszai Halfesztival in Szeged, Transylvania international film festival in Kluj Napolka, Martisoreulspring customs, over the Romania, Wine Festival and International Country and Folk Music Festival in Timisoara, Festival of medieval arts and crafts, "Medieval sigishoara", Celebration of campulung of Tisa in Romanian settlements near the Tisa, Duzijanca in Subotica, Days of the New Bread in Kanjiza, International Festival of Folklore "Vrsacki venac" and Vintage Days in Vrsac, International Festival of Folklore in Sombor, Fishing festival "Zlatna bućka" on Danube, Donji Milanovac, etc. (www. hungarytourism.hu; romaniatourism. com; Bjeljac at all, 2002).

\section{Tourist regions of the frontier area}

The arrangement of natural and anthropogenic tourist assets indicates the concentration in the narrow areas that are usually close to the transitional tourist directions. Their arrangement shows that some of them are specially connected, while some of them are not. In order to emphasize the attractiveness and uniqueness of the tourist assets (in terms of the most adequate tourist use), tourist assets are grouped in larger and smaller special entities- regions (in the spaces towards which tourist migrations are directed)

In the territory of Serbia tourist assets of the frontier area close to Romania are divided in the tourist regions Banat sandy terrain, Lower Tisa, Djerdap (Bursac, Bjeljac 2001). In the territory of Romania tourist assets of the frontier area close to Serbia are divided in the tourist regions: Western Hills and Plain, Getici plateau and Getici Subcarpathians, Banat mountain and Romanian plain. (Surd, Cocean, 1996). Natural geographical connecting areas show that tourist potentials make a unique, attractive space. There are also important transit spaces, area which placed traffic service Corridor 7 (Danube). International traffic road M7 (Zrenjanin - Srpska Crnja Jimbolia-Timisoara), Romania is connected with so-called Banat highway (BeogradZrenjanin-Szeged) and traffic direction E7o (Belgrade-Vrsac-Timisoara-Bucur- 
est). These highways as traffic directions, near Belgrade, connected Romania with Pan European Corridor 10. By observing the border between Serbia and Romania, one can notice certain complementarily of the natural and anthropogenic tourist assets, divided into the mentioned tourist regions.

In the territory of Serbia tourist assets of the frontier area close to Hungary are divided in the tourist regions: Upper Danube and Upper Tisa. (Bjeljac et all 2002). In the territory of Hungary tourist assets of the frontier area close to Serbia are divided in the tourist region: South Hingarian and Delnyugat-Magyarorszag (Bodnar, 2000, Tunde 2001). Natural geographical connecting area (Pannonian plain, BajaSubotica-Horgos sandy terrain) show that there are important transit spaces with tourist potentials. The main land communications pass through the territories of municipalities in the border area. They present the part of the international Corridor 10 B. Municipalities of Subotica and Kanjiza show their correlation with the surrounding and the neighboring Hungary (Szeged) by the system of radial passengers directions of the highest level: towards Sombor (and towards Croatia , M 17), direction of Corridor (E75), towards Kanjiza to "Banat highway" (Tisa valley), and Kikinda to Romania. There are also important transit river direction which placed Danube river as traffic Corridor 7 , and so called Danube highway (Baja-Sombor-Novi Sad-Belgrade-Corridor 10).

In the territory of Romania tourist assets of the frontier area close to Hungary is divided in the tourist region: Western Hills and Plain. This region belong in group of mixed tourist areas "coexistence of some varied resources that appeal in the same measure to recreational as well as to the curative and cultural tourism"(Surd, Cocean, 1996). In the territory of Hungary tourist assets of the frontier area close to Romania is divided in the tourist region South Hungarian (Del-Alfeld).

These facts make possibilities in expanding of tourist destinations and other connections (economic, cultural, etc) as well as in international connections similar anthropogenic and natural tourist potentials (Bjeljac, Radovanovic, 2002).

\section{Tourism in the frontier space a part of the economical and regional development}

The complimentarily of the tourist assets indicates the possibility of mutual monitoring, marketing and management, thus, as a single tourist destination; it would take a significant part in global tourist migrations. "The arrangement of the international relationships in the field of over limited migrations of people represents a complex and various problematic, from the control of the outer and interior borders and a fight against various kinds of criminal and terrorism, over passport treatment and treatment of strangers, to a guarantee of security of their stay in the territory of one state. The complexity of this issue is enlarged in great deal by the existence of various kinds of over limited migrations of people. One of them, considered to be the most numerous, is treated as the international tourist traveling. The international tourist traveling became really numerous during the second part of the $2 \mathrm{O}^{\text {th }}$ century, with tendencies of permanent enlarging."(Maric, 2000). Tourist potentials and their complementary make possible, more than anything else, the economical development of the frontier area. That will also affect the improvement of bilateral relationships, especially in making the collective actions for the protection and the rational use of resources.

In a context with those citations, customs, folklore, ways of living and entire economic development are present in those tourist regions. Tourist assets in those border areas stress the common life and cooperation of all the nationalities in various fields of human action and economy. In other words, there is the possibilities for stronger cooperation between Serbia, Romania and Hungary and as well as with other countries in the region. Euro region Danube-Tisa-Kris-Mures on SerbianHungarian and Romanian point of three border areas lines and Djerdap on Serbian - Romanian border areas have potentials that as international tourist destinations and regions became wery important part of global tourist market.

Euro region Danube-Kris-Moris-Tisa (DKMT), as European region is consist from 4 regions in Romania, 3 regions in Hungary and 1 region in Serbia. As mini region which are characteristics: geographical closeness, Danube tributary Tisa (with own tributaries Kris and Mures) and Danube, since this region get also and European dimension, multifarious population in euro region as entirety and in each part individually, similar and compatibly economic structure, similar cultural-historical tradition, have possibilities for intensively cross-border cooperation. DKMT region is also part of three crossborder tourist regions (Upper Tisa in Serbia, Del Alfeld in Hungary and Western Hills and Plain in Romania). With this position DKMT region have possibilities for becoming relatively independent European tourist destination.

Combined natural and developed assets and the cultural heritage of Djerdap sector of the Carpathian region make this area a relatively independent tourist space in Serbia and Romania, which implies very close bond and cooperation with the complementary tourist region. Serbia, Hungary (with eight counties), and Romania (with 12 Danube districts) are members of the regional Danube organization Arbeitsgemeintschaft Donaulander, which also get European dimension.

With entering of Hungary (in 2004 year) and Romania (on 2007 year) in European Union significance for region is the development strategy, which is planned by the European Union to be realized by certain development politics has its aim, and that is to define the wide parameters of a reasonable and universal approach to the regional development in the Southern Europe. The strategic base for the regional activities is very wide and is strongly based on the positions of maintainable development." (Marjanovic, 200o). The programme - development priorities of the regional politics of the European Union (the production investments (apart from the other things, related to the tourism (hotel trade)), making easer opening the new employment positions and waintaining the existing ones), infrastructural equipping and equipping of the public services (apart from the others, the development of trans Europe traffic, energetic and telecommunicating net, realizations of the building projects and completing the local roadways, bridges, airports and telecommunication systems in the isolated areas in order to connect them better with the other parts of the European Union; the realization of the project for improving and protecting the environment; the realization of the projects that are focused on the development of tourism), the business environment/the internal development (the general organization and promotion of the projects for the development of tourism), the professional training, development of the villages (development and improving of the country tourism and handicrafts), (Bugarin, Simeunovic, 1999) which are, available because of the Pact for the Stability of the South East Europe and Process of collaboration on Southeast Europe and the programs instruments PHARE and INTERREG programs (the adaptation of the firms of the public and private sector, the development of the basic regional infrastructure, including the over limited cooperation) and the ways of motivation for the joint venture, indicate the possibility of including as a frontier region and attractive tourist destination in the European regions

\section{Conclusion}

The tourist assets of the frontier area between Serbia, Hungary and Romania indicate the possibility of a stronger ways of mutual, bilateral cooperation, as well as 
cooperation with the other countries in the region and states in the European Union. Governments of those countries must search for such a kind strategies, which will be making possibilities for growth in assets on natural and anthropogenic resources. In same time, those resources must be protected and with economic sustainable development. Considering the various natural and anthropologic tourist assets, the infrastructure (traffic, tourism), the great economic significance of the outlandish circulation and consumption, it is doubtless that have a great interest in realizing international tourist migrations as large as possible. The organization of the tourism of the level of Euro regions would also represent the extraordinary possibilities for development of tourism. For realizing of tourism development on this level, there must existence coordination between creators on economic politics in states of region. In other words, coordination between individual (national) strategies of tourism development is necessary, because using of synergetic effect in this area. Cited complementarities in this work present complementary tourist products, which will be enable consistent approach into tourist develop. Examples in cross-border cooperation are: political ${ }^{3}$, scientific ${ }^{4}$, economical, cultural, ecological cooperation in aim of protection and valorization economic and demographic resources with primary develop of tourism (transit, eco-, rural, event, cultural, spa, event) as model of space valorization.

\section{Acknowledgements}

This paper work represent research in project 146011 financed by Ministry on Sciences Republic of Serbia

As well as DKTM region meetings

4 Such as conferences: "Simpozionului Banatul trecut istoric si cultural" in Novi Sad and Resita, The Regional conference of geography "Geographic researches in the Carpathian -Danube space in Timisoara", "Hatarok es a Europai Unio" in Szeged).

\section{References}

Bjeljac, Ž. 2001. Potentiaul turistical Banatulul, Actele simpozionului Banatul Iugoslav trecut istoric si cultural, Novi Sad, Societatea (Fundatia) Romana de etnografie si folclor din Vojvodina, Novi Sad, pp 26-34

Bjeljac, Ž. 2002. Comparative analysis on tourist regionalization of Serbia, Romania, Bulgaria and FYR Macedonia, Collection of paper from International scientific conference „In memory of Prof. Dimitar Jaranov“, Varna, book 3,"Geopolitics, Regional development, Geographical education", pp. 157-168.

Bjeljac, Ž., Radovanović M. 2002. Comparative analyses between tourist regionalization of Serbia and Romania, the $5^{\text {th }}$ edition of The Regional conference of geography „Geographic researches in the Carpathian - Danube space- „The reconsideration of the geographic approach in the context of globalization", pp. 619-626, Timisoara.

Bjeljac Ž., Ćurcić N., Dobrivojević O. 2002. The Development Possibilities of Tourism in Subotica and Kanjiza Municipalities as a part of Economic Development in the Border Area Hatarok es a Europai Unio, pp.451-458, Szeged.

Bjeljac Ž., Štrbac N, Curcić N in press. Turizam u pogranicnom prostoru Srbije prema $\mathrm{BiH}$, Zbornik radova Geografskog fakulteta Univerziteta u Beogradu.

Bjeljac, Z, Bursać, M 2006. Turizam u pogranicnim krajevima Srbije, kao mogucnost saradnje sa drzavama u regionu, Zbornik radova sa naucnog skupa, "Srbija i savremeni procesi u Evropi i svetu”, planina Tara, Geografski fakultet Univerziteta u Beogradu, pp.731-736.

Bodnar, L. 200o. A Turizmus foldrajzi alapjai, Nemzeti Tankonyvkiado, Budapest,

Bugarin, S., Simeunović, L. 1999. Regionalna politika Evropske Unije. Zbornik radova "Regionalni razvoj i demografski tokovi Balkanskih zemalja”. Ekonomski fakultet Univerziteta u Nišu, 4, pp 13-26.

Bursać, M, Bjeljac, Ž. 2001. Regiunile turistice Banatul, Actele simpozionului Ba- natul Iugoslav trecut istoric si cultural, Novi Sad, pp. 100-105. Societatea (Fundatia) Romana de etnografie si folclor din Vojvodina,

Hall, D. 2004. Key themes and frameworks In D.Hall (ed) Tourism and Transition: Governance, Transformation and Development, Wallingford, UK, CABI Publishing, pp.217-226

Hall, D. 2006. Tourism and the transformation of European space, in "The transformation of tourism spaces, ATLAS Reflections 2006, September 2006, Smith M, Onderwater L (eds), pp.11-25

Liszewski S (2006) Tourism spaces and their transformation in "The transformation of tourism spaces, ATLAS Reflections 2006, September 2006, Smith M, Onderwater L (eds), pp.7-8

Marić, R. 200o. Prekogranicna kretanja ljudi ipozicija SR Jugoslavije u regionu Balkana Zbornik radova „Regionalni razvoj i demografski tokovi Balkanskih zemalja, Ekonomski fakultet, Univerziteta u Nisu, book. 5 pp. 189-198

Mitrović, Lj. 2001. Regionalizam kao razvojni faktor i osnova integracije Balkana Zbornik radova "Regionalni razvoj i demografski tokovi Balkanskih zemalja,, Ekonomski fakultet Univerziteta u Nišu 6, pp 43-48.

Surd V, Cocean, P. 1996. Tourist regionalization of Romania, Collection of paper from conference "Tourist potentials of Yugoslavia” pp.199-202, Institute for Geography, Faculty of Natural sciences, University in Novi Sad,

Tunde J, (2001), The development possibilities of tourism in the South-East Hungarian Region, in journal Turizam, no.5, pp. 29-31, Department for Geography, Tourism and Hospitality, Faculty of Natural sciences, University in Novi Sad

Vemić M, Mijović, D, Štrbac, D. 2003. Ecotourism in Djerdap area of Carpathian region, Collection of paper from conference "The development and potentials of ecotourism on Balkan peninsula”, vol.1, pp. 23-32, Belgrade

www. hungarytourism.hu

www. romaniatourism.com 